\title{
Seed Health and Viability of Commiphora lepthophloeos (Mart.) J.B. Gillet after Dehydration and Storage
}

\author{
Antonieta N. Salomão, Marta G.R. Faiad, and Rozane Cunha \\ Centro Nacional de Pesquisa de Recursos Genéticos e Biotecnologia, P.O. \\ Box 02372, 70849 Brasília-DF, Brazil
}

Additional index words. seed germination, fungal infection, desiccation tolerance

Commiphoralepthophloeos (Burseraceae) is a multipurpose tree (pharmaceutical and wood products) from Brazilian semi-arid regions, and its seeds germinate poorly (slowly and intermittently) due to coat hardness. Our study was undertaken to determine how moisture content and storage temperature influence C. lepthophloeos germination and seed health and to establish storage conditions for longterm seed conservation.

Seeds from several maternal plants were collected from the ground at Petrolina-Brazil, surface-sterilized in $5 \% \mathrm{NaOCl}$ for $10 \mathrm{~min}$, washed twice in distilled water, and dried at room temperature for 1 day. Seeds were dehydrated at $22 \mathrm{C}, 15 \%$ relative humidity for 0 (control), 96, 168, and $192 \mathrm{~h}$. After each dehydration period, seeds were placed in sealed, impermeable plastic bags and stored for 12 months at -20 and $10 \mathrm{C}$ and ambient temperatures that varied from 24 to $30 \mathrm{C}$. For each dehydration-storage combination, moisture content was determined after oven-drying at $105 \pm 3 \mathrm{C}$ for $24 \mathrm{~h}$ using two replications of 20 seeds each. Germination tests were conducted on four replications of 20 seeds each on moist rolled paper towels under a 20/30C cycle $(16 / 8 \mathrm{~h})$ for each desiccation-storage combination. Germination was recorded daily for 90

Received for publication 27 June 1995. Accepted for publication $29 \mathrm{Feb} .1996$. The cost of publishing this paper was defrayed in part by the payment of page charges. Under postal regulations, this paper therefore must be hereby marked advertisement solely to indicate this fact. days. A seed was considered to have germinated when all structures could be judged to be developing normally. Data were transformed by arcsin and tested by analysis of variance followed by Tukey's test at $P \leq 0.05$ (Snedecor and Cochran, 1963).

The health test was conducted on four replications of 25 seeds each that had been sterilized in $70 \%$ alcohol for 1 min then soaked in $1 \% \mathrm{NaOCl}$ for $10 \mathrm{~min}$. Seeds were placed on moist filter paper in petri dishes and incubated at $20 \mathrm{C}$ for 7 days under alternating ultraviolet light and in darkness (12/12 h). Developing mycoflora were identified and quantified by stereoscopic microscope examination.

Commiphora lepthophloeos seed germination appeared to be unaffected by dehydration to $\approx 40 \%$ of the initial moisture content, whether tested initially (range $7 \%$ to $11 \%$ ) or after 12 months (range $17 \%$ to $22 \%$ ). Because C. lepthophloeos naturally grows in semi-arid conditions, it might be expected that the seeds would be able to withstand drying to a low moisture content (Sun and Leopold, 1993). In our tests, desiccation injury was probably avoided because the seeds were collected after maturation drying was complete (Hong and Ellis, 1990).

Significant differences in germination percentages were found among seeds stored for 12 months at three temperatures (Table 1). Germination following storage at ambient temperatures was higher than following storage at $10 \mathrm{C}$ but similar to that at $-20 \mathrm{C}$.

An abundant mycoflora represented by 11 species of potentially pathogenic fungi and 12 species of saprophytic fungi was detected. There were high infection percentages for Aspergillus niger van Tieghem (92\%), A. flavus Link ex Fr. (60\%), Cladosporium sp Link ex Fr. (61\%), Fusarium oxysporum Schlecht (50\%), Penicillium sp Link ex Gray (57\%), and Rhizopus sp. Ehrenb. ex Corda $(92 \%)$. These fungi persisted on the seeds after storage under all three conditions.

Our results suggest that $C$. lepthophloeos seeds are desiccation tolerant and are not sensitive to storage at low temperatures. Adequate sanitation methods need to be developed before seed storage because persistent fungal infection could compromise seed longevity in gene bank conservation.

\section{Literature Cited}

Hong, T.D. and R.H. Ellis. 1990. A comparison of maturation drying, germination, and desiccation tolerance between developing seeds of Acer pseudoplatanus L. and Acer platanoides L. New Phytol. 116:589-596.

Snedecor, G.W. and W.G. Cochran. 1968. Statistical methods, 6th ed. Iowa State Univ. Press, Ames.

Sun, W.Q. and A.C. Leopold. 1993. Acquisition of desiccation tolerance in soybeans. Physiol. Plant. 87:403-409.

Table 1. Commiphora lepthophloeos seed moisture content (MC) and germination percentage after storage at three temperatures for 12 months.

\begin{tabular}{|c|c|c|c|c|}
\hline \multirow{2}{*}{$\begin{array}{l}\text { Drying periods } \\
\text { (h) }\end{array}$} & \multirow{2}{*}{$\begin{array}{l}\mathrm{MC} \\
(\%)\end{array}$} & \multicolumn{3}{|c|}{ Germination (\%) } \\
\hline & & Ambient & $10 \mathrm{C}$ & $-20 \mathrm{C}$ \\
\hline$\overline{0}$ & 6.9 & 37 & 9 & 24 \\
\hline 96 & 2.9 & 23 & 18 & 20 \\
\hline 168 & 2.8 & 37 & 27 & 15 \\
\hline 192 & 2.6 & 23 & 13 & 21 \\
\hline $\begin{array}{l}\text { Storage } \\
\quad \text { germination means }\end{array}$ & & $30 \mathrm{a}$ & $17 \mathrm{bc}$ & $21 \mathrm{ab}$ \\
\hline
\end{tabular}

